\title{
Effects of different regimes of metyrapone on steroid production by a patient with a corticotrophin secreting bronchogenic carcinoma
}

\author{
Judith M. SteEL \\ M.B., Ch.B. \\ Senior House Officer, \\ Department for Endocrine and Metabolic Diseases, \\ Western General Hospital, Edinburgh
}

THE SECRETION of hormones or closely related substances by tumours arising from tissues other than the endocrine glands has been widely reported and was reviewed recently by Bower \& Gordan (1965) and Anderson (1966). The commonest example is the production of adrenocorticotrophic hormone (ACTH) by some oatcell carcinomas of the bronchus (Brown, 1928 ; Christy, 1961 ; O'Riordan et al., 1966; and others). The prognosis in this condition is even worse than with non-hormone producing oat-cell carcinomas, as high plasma levels of corticosteroids have been claimed to increase tumour growth and spread (Green \& Whiteley, 1952 ; Wolf et al., 1960; Sherlock \& Hartmann, 1962).

Many attempts have been made to treat the associated adrenocortical hyperfunction but with little successs. Metyrapone (SU-4885, 1,2-bis (3 pyridyl)-2 methyl-1 propanone, 'metopirone'. Ciba) inhibits the enzyme 11- $\beta$-hydroxylase, which is essential for the final step in the synthesis of 11-hydroxycorticosteroids (11-OHCS), of which the most important in man is cortisol (Friedman, Marshall-Jones \& Ross, 1966 ; Meador et al., 1962 ; Mattingly et al., 1964). There have been few studies of the value of this drug in treating patients with corticotrophin-secreting tumours (Mattingly et al., 1964 ; Hugh-Jones, 1964 ; O'Riordan et al., 1966). O'Riordan et al. (1966) treated two patients with ACTH-secreting tumours, one with a bronchogenic carcinoma who showed very little improvement and one with an anaplastic carcinoma of the thyroid gland who responded well for several months. The dose of metyrapone used was $0.75 \mathrm{~g}$ at intervals of $6 \mathrm{hr}$.

Treatment with metyrapone in doses at intervals of $6 \mathrm{hr}$ has usually proved unsatisfactory. There is evidence, however, that more adequate

\author{
A. A. H. LAWSON \\ M.B., Ch.B., M.R.C.P.E. \\ University Lecturer in Medicine, \\ Western General Hospital, \\ Edinburgh
}

suppression of plasma 11-OHCS can be obtained by administering the drug at intervals of $2 \mathrm{hr}$. J. G. Sprunt (personal communication, 1967) has shown that the $11-\beta$-hydroxylase-inhibiting activity of metyrapone has a half-life of $26 \mathrm{~min}$. Buus, Binder \& Petersen (1962) previously demonstrated that in normal people, metyrapone when given 4-hourly produces poor suppression of plasma 11-OHCS, but complete inhibition if given every $2 \mathrm{hr}$.

The purpose of this communication is to describe the effects of different dosage regimes of metyrapone (the total amount administered per $24 \mathrm{hr}$ remaining constant) in a patient presenting with severe adrenocortical hyperfunction associated with an oat-cell carcinoma of the bronchus secreting ACTH.

\section{Case report}

The patient was a 63-year-old housewife with known mild rheumatic heart disease involving the aortic and mitral valves. She presented with a history of an unproductive cough and dyspnoea on exertion for the previous 8 weeks. In the final week she developed rapidly increasing generalized oedema and marked lassitude. Her face then suddenly became swollen, suggesting obstruction of the superior vena cava, and this led to her admission as an emergency.

Her general appearance with slight hirsutism of the upper lip and vitiligo of the chest and arms was clearly in keeping with a diagnosis of Cushing's syndrome. She was extremely weak, being unable to sit up in bed unsupported. There was generalized oedema. Stridor was audible on deep inspiration. There was non-pulsatile distension of the left internal jugular vein. Blood pressure $160 / 90 \mathrm{mmHg}$. The heart was moderately enlarged but no change was found in the signs 
of rheumatic heart disease noted previously. The liver edge was just palpable.

Investigations: Chest $\mathrm{X}$-ray: a large mass at the left hilum. Plasma sodium $140 \mathrm{mEq} / 1$, potassium $2.4 \mathrm{mEq} / 1$, chloride $98 \mathrm{mEq} / 1, \mathrm{CO}_{2}$ combining power $27.5 \mathrm{mEq} / 1$, urea $26 \mathrm{mg} / 100 \mathrm{ml}$. Glucose tolerance test: fasting plasma glucose $122 \mathrm{mg}$ / $100 \mathrm{ml}$; after $50 \mathrm{~g}$ glucose by mouth; (plasma glucose levels at $30 \mathrm{~min}$ intervals), 169, 196, 200. 200 and $160 \mathrm{mg} / 100 \mathrm{ml}$. Plasma 11-OHCS. Plasma fluorescence $\equiv 40 \mu \mathrm{g}$ of $11-\mathrm{OHCS} / 100 \mathrm{ml}$ at 11 p.m. and $42 \mu \mathrm{g} / 100 \mathrm{ml}$ at 9 a.m. (normal range 7-27 $\mu \mathrm{g} / 100 \mathrm{ml}$, Mattingly, 1962). Urinary 17-oxosteroids: $11 \cdot 1 \mathrm{mg} / 24 \mathrm{hr}$ (normal range $5-15 \mathrm{mg} / 24 \mathrm{hr}$, Norymberski, Stubbs \& West, 1953). Urinary 17-OHCS: $50 \mathrm{mg} / 24 \mathrm{hr}$ (normal range $5-15 \mathrm{mg} / 24 \mathrm{hr}$, Appleby et al., 1955). Plasma ACTH level $2.28 \mathrm{mUnits} / 100 \mathrm{ml}$ (upper limit of normal $1 \mathrm{mUnits} / 100 \mathrm{ml}$ plasma. Index of precision for the assay $=0 \cdot 17$. VernikosDanellis, Anderson \& Trigg, 1966). Exchangeable body potassium $=25.4 \mathrm{mEq} / \mathrm{kg}$ (predicted normal $=35 \mathrm{mEq} / \mathrm{kg}$, Aikawa, Hassell \& Eisenberg, 1952). Total body potassium $=75 \mathrm{~g}$ (predicted normal $=94.5 \mathrm{~g}$, Oberhausen \& Onstead, 1965). Bronchoscopy showed narrowing of the main carina with nodular tissue protruding from the inferior margin of the left upper lobe bronchus. Biopsy from left upper lobe bronchus: biopsy showed columnar bronchial epithelium; submucosa was infiltrated by an oat-cell carcinoma.

\section{Treatment and progress}

Treatment at first with oral potassium supplements in the form of a mixture of potassium bicarbonate and potassium chloride, providing a total dose of $63 \mathrm{mEq} \mathrm{K} /$ day, had no effect on the level of her serum potassium.

Three weeks later she received a course of palliative radiotherapy which reduced the size of the primary tumour dramatically; the distension of the left jugular vein disappeared.

Despite the shrinkage of the tumour the features of Cushing's syndrome increased and the hypokalaemia persisted. It was therefore decided to treat the patient with metyrapone. She was given the drug by mouth $4.0 \mathrm{~g} / 24 \mathrm{hr}$, initially in a dose of $1.0 \mathrm{~g}$ at intervals of $6 \mathrm{hr}$ for one period of $24 \mathrm{hr}$. Immediately thereafter the dose regime was changed to $500 \mathrm{mg}$ at 6.00 a.m., $250 \mathrm{mg}$ at 8.00 a.m., $500 \mathrm{mg}$ at 10.00 a.m. and 12 noon, $250 \mathrm{mg}$ at 2.00 p.m., $500 \mathrm{mg}$ at 4.00 p.m., $250 \mathrm{mg}$ at 6.00 p.m., $500 \mathrm{mg}$ at 8.00 and 10.00 p.m. and $250 \mathrm{mg}$ at 2 a.m. Plasma 11-OHCS were estimated (Mattingly, 1962) at intervals throughout these two periods of treatment with mety- rapone (Fig. 1). Comparison of the mean levels of 11-OHCS showed no significant difference, though it did appear that the fluctuations in plasma 11-OHCS were less with the 2-hourly regime. For this reason it was decided to continue long-term treatment with this regime modifying it slightly in that the 2 a.m. dose was

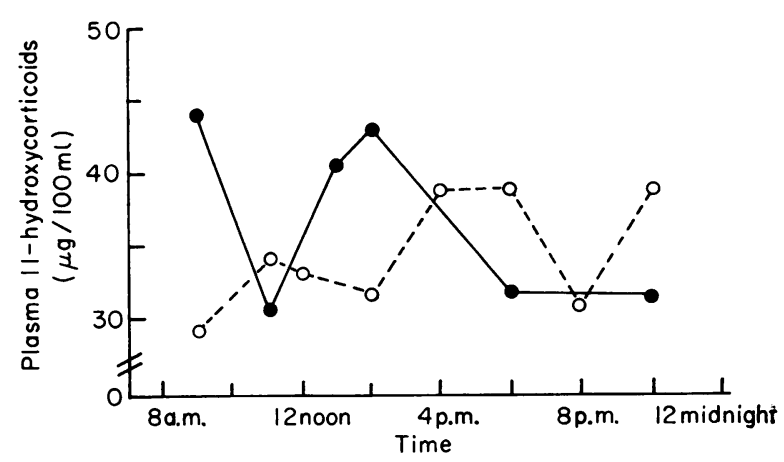

FIG. 1. Effects of plasma 11-OHCS of two dosage regimes of oral metyrapone given over two 24 -hr periods. response to metyrapone 6-hourly (mean $37.3 \mu \mathrm{g} / 100 \mathrm{mI}$ ); $\mathrm{O}$, response to metyrapone 2 -hourly (mean $34.6 \mu \mathrm{g} / 100$ $\mathrm{ml})$.

omitted but the total dose of $4.0 \mathrm{~g} / 24 \mathrm{hr}$ was maintained by increasing the $8.00 \mathrm{a} . \mathrm{m}$. dose to $500 \mathrm{mg}$. Soon after this the serum potassium rose to within the normal range but a few days later total body potassium measured by whole body counting of $40 \mathrm{~K}$ and exchangeable potassium determined by $42 \mathrm{~K}$ studies remained low (see above). The plasma 11-OHCS fell slightly and the urinary 17-OHCS rose (Fig. 2). Clinically she improved slightly in that her generalized weakness became less marked and after 6 weeks she was able to return home. Five weeks later, however, she had become virtually bedridden and required readmission to hospital. Facial hirsutism had increased considerably; skin pigmentation and vitiligo by this time were much more severe than previously. She was severely wasted, but did not at any time become hypertensive the highest recorded BP being 170/100. Also she did not become alkalotic, as judged by the highest plasma $\mathrm{CO}_{2}$ combining power of $72.5 \mathrm{mEq} / 1$ and a persistently normal plasma chloride (range $95-106 \mathrm{mEq} / 1)$. In view of the striking deterioration in her clinical condition metyrapone treatment was withdrawn. Following this, she deteriorated even more rapidly, becoming almost immobile and drowsy. Estimation of her plasma 11-OHCS levels, 10 days after discontinuing metyrapone, showed that these had risen to $96 \mu \mathrm{g} / 100 \mathrm{ml}$. Her fasting blood sugar rose to 
$416 \mathrm{mg} / 100 \mathrm{ml}$ and the plasma $\mathrm{CO}_{2}$ combining power fell to $18 \mathrm{mEq} / \mathrm{l}$. Urinalysis showed continuous glycosuria of more than $2.0 \%$ and ketonuria. She died 12 days after metyrapone therapy was stopped.

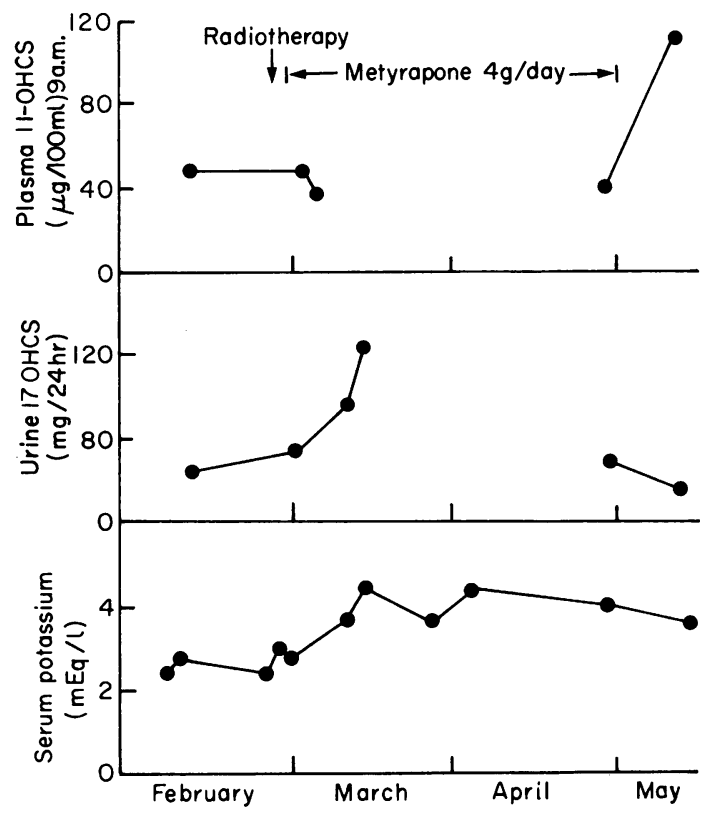

FIG. 2. Results of prolonged treatment with metyrapone $(4.0 \mathrm{~g} / 24 \mathrm{hr})$ on serum potassium, plasma 11-OHCS and urinary $17-\mathrm{OHCS}$.

Necropsy. The left lung showed thickening by tumour around the main bronchus. There were massive nodular metastases in the liver and vertebral column and bilateral adrenal cortical hyperplasia, the glands weighing 13 and $16 \mathrm{~g}$ respectively. No tumour tissue was found in the adrenals. The pituitary gland appeared normal.

\section{Discussion}

This patient showed several unusual and striking features. In previously reported cases of this type (Bagshawe, 1960) a hypokalaemic alkalosis was always noted and was thought to be a useful means of distinguishing simple bilateral adrenal hyperplasia from that associated with a corticotrophin-producing malignant tumour. Bagshawe (1960) reported eighteen cases of nonadrenal malignant tumours associated with Cushing's syndrome. All had potassium levels below $3 \mathrm{mEq} / 1$ and total $\mathrm{CO}_{2}$ levels between 31 and $52 \mathrm{mEq} / 1$. Alkalosis was not demonstrated in our patient and is not, therefore. an invariable finding in patients with ACTH-secreting tumours. It is possible that the patient may have been catabolizing so much body tissue that she was producing large quantities of acid metabolites which would serve to neutralize the alkalosis usually produced by corticosteroids.

Most authors, including Borstein, Nolan \& Bernanke (1961) and O'Riordan et al. 1966), state that the typical features of Cushing's syndrome occur rarely in the presence of an ACTH-secreting carcinoma, and then only in patients whose tumours grow slowly with relatively moderate production of ACTH. The prognosis is also said to be better in these patients (Bower \& Gordan, 1965). Many of the classical features of Cushing's syndrome, notably facial swelling, hirsutism and pigmentation, developed extremely quickly in this patient. These were associated with rapidly growing metastases which presumably were responsible for the high plasma level of ACTH found and the high levels of plasma 11-OHCS. Clinical deterioration was also very rapid.

An attempt was made to suppress the secretion of cortisol by using metyrapone 2-hourly, the total daily dose being $4.0 \mathrm{~g}$. During this treatment the patient, after an initial slight improvement, continued to deteriorate clinically. On the other hand, the hypokalaemia seemed less severe, allowing adequate replacement by oral therapy. The diabetic state also remained mild. After withdrawal of metyrapone, however, extremely rapid deterioration both clinical and biochemical occurred. The treatment therefore appeared to slow the progress of the disease and to modify the biochemical abnormality thus perhaps contributing to the general wellbeing of the patient. The rise in urinary $17-\mathrm{OHCS}$ after starting treatment with metyrapone was probably due to increased ACTH production by the tumour. A rise in 17-OHCS in response to metyrapone is uncommon in such patients because the existing level of ACTH is often so high that adrenal responsiveness to additional ACTH is minimal (Meador et al., 1962). The subsequent fall of the urinary 17-OHCS while still on metyrapone is difficult to explain, but similar observations were made by Mattingly et al. (1964) on two patients given metyrapone for several days. One of these patients was extremely ill and oliguric, and the findings were thought to be due to an alteration in the renal handling of conjugated steroids. The other patient was not oliguric and Mattingly et al. (1964) suggested that metyrapone was possibly blocking other enzymes besides $11-\beta$-hydroxylase.

In the patient described here, the tumour was growing very rapidly and generalized carcinoma- 
tosis soon became apparent. In selected patients, therefore, and particularly in the slowly growing ACTH producing tumours, which have been previously described (O'Riordan et al., 1966), metyrapone may be of value in reducing the distressing effects of hyperadrenocorticism. With a rapidly growing tumour metyrapone is probably ineffective and another approach with, for example, aminoglutethimide (Elipten, Ciba) would now be more appropriate.

\section{Acknowledgments}

Acknowledgments are gratefully made to Professor J. A. Strong for allowing us to report this case and for his help and criticism, to Dr W. P. Duguid of the Department of Pathology, Royal Infirmary, Glasgow, for undertaking the ACTH bioassays, to Dr F. L. Mitchell, The Department of Clinical Chemistry, Royal Infirmary, Edinburgh, for the plasma 11-OHCS estimations, to Dr D. B. Horne of the Department of Clinical Chemistry, Northern General Hospital, Edinburgh, for the 17-OHCS estimations and to Dr N. Maclean for autopsy data.

\section{References}

Aikawa, J.K., Hassell, G.T. \& Eisenberg, B. (1952) The exchangeable potassium content of normal women. J. clin. Invest. 31, 367.

ANDERSON, E.G. (1966) Non-metastatic syndromes associated with carcinoma of the bronchus. 1. The endocrine syndromes. Hosp. Med. 1, 11 .

Appleby, J.I., Gibson, G., Norymberski, J.K. \& STUbBS, R.D. (1955) Indirect analysis of corticosteroids. 1. The determination of 17-hydroxycorticosteroids. Biochem. J. 60, 453.

BAgshaWe, K.D. (1960) Hypokalaemia, carcinoma and Cushing's syndrome. Lancet, ii, 284.

Borstein, P., Nolan, J.P. \& Bernanke, D. (1961) Adrenocortical hyperfunction in association with anaplastic carcinoma of the respiratory tract. New Engl. J. Med. 264, 363.
BOWER, B.F. \& GoRdAN, G.S. (1965) Hormonal effects of non-endocrine tumours. Ann. Rev. Med. 16, 83.

Brown, W.H. (1928) A case of pluriglandular syndrome. Diabetes of bearded women. Lancet, ii, 1022.

Buus, O., Binder, C. \& Petersen, F. (1962) Metopirone dosage in pituitary function tests. Lancet, $\mathrm{i}, 1040$.

ChRISTY, N.P. (1961) Adrenocorticotrophic activity in the plasma of patients with Cushing's syndrome associated with pulmonary neoplasms. Lancet, i, 85.

Friedman, M., Marshall-Jones, P. \& Ross, E.J. (1966) Cushing's syndrome: adrenocortical hyperactivity secondary to neoplasm. Quart. J. Med. 35, 193.

Green, H.N. \& Whiteley, H.J. (1952) Cortisone and tumour growth. Brit. med. J. ii, 538.

Hughes-Jones, P. (1964) A case of carcinoma of the lung with endocrine changes. Brit. med. J. i, 1492.

Mattingly, D. (1962) A simple fluorimetric method for the estimation of free 11-hydroxycorticoids in human plasma. J. clin. Path. 15, 374.

Mattingly, D., Keans, P.M., McCarthy, C.F. \& Read, A.E. (1964) Adrenoccrtical hyperfunction and oat-cell carcinoma of the bronchus. Bristol med. chir. J. 79, 6.

Meador, C.K. Liddle, G.W., Island, D.P., Nicholson, W.E., LuCAS, C.P., Nuckton, J.C. \& Luetscher, J.A. (1962) Cause of Cushing's syndrome in patients with tumours arising from 'non-edocrine' tissue. J. clin. Endocr. 22, 693.

NoRYMberski, J.K., Stubis, R.D. \& WeST, H.F. (1953) Assessment of adrenocortical activity by assay of 17ketogenic steroids in urine. Lancet, i, 1276.

Oberhausen, E. \& ONSTEAD, C.O. (1965) Radioactivity in Man, p. 179. Thomas, Springfield.

O'Riordan, J.L.H., BlanshaRd, G.F., Moxham, A. \& Nabarro, J.D.N. (1966). Corticotrophin-secreting carcinomas. Quart. J. Med. 35, 137.

Sherlock, P. \& Hartmann, W.H. (1962) Adrenal steroids and the pattern of metastases of breast cancer. J. Amer. med. Ass. 181, 313.

Vernikos-Danellis, J., Anderson, E. \& Trigg, L. (1966) Changes in adrenal corticosterone concentration in rats. Method of bioassay for ACTH. Endocrinology, 79, 624.

Wolf, J., Spear, P., Yesner, R. \& Patno, M.E. (1960) Nitrogen mustard and the steroid hormones in the treatment of inoperable bronchogenic carcinoma. Amer.J. Med. 29, 1008.

\title{
Granulosa-cell tumour of the ovary causing sexual precocity in a girl aged $3 \frac{1}{2}$ years
}

\author{
Richard H. ParrotT \\ M.B., B.S., D.Obst.R.C.O.G., M.R.C.G.P. \\ General Practitioner, St Germans, Cornwall
}

According to Eberlein et al. (1960) isosexual precocity in girls may be arbitrarily defined as the appearance of feminine secondary sexual characteristics before the age of 7 years or menstrual bleeding before the age of 8 . The majority of such cases are 'idiopathic' or 'constitutional'; there is a true precocious puberty, gonadotrophins being present and ovulation occurring, and there is no reversal of the early pubertal development.

A rare cause of sexual precocity is the presence of functioning ovarian tumours which are usually granulosa-cell or theca-cell tumours. In these cases gonadotrophins are not usually 